\title{
TRADICIJSKA GLAZBA ISTRE U NASTAVI GLAZBENE KULTURE NIŽIH RAZREDA OSNOVNE ŠKOLE
}

\author{
Snježana Močinić \\ Sveučilište Jurja Dobrile u Puli, Fakultet za odgojne i obrazovne znanosti \\ Pula, Hrvatska \\ Marija Crnčić Brajković \\ Pula, Hrvatska
}

\begin{abstract}
Sažetak:
Tradicijska glazba utkana je u životu svake ljudske zajednice te se u njoj odražava način razmišljanja i stil života ljudi koji su ju stvarali, očuvali i prenosili mlađim generacijama. Osim što je izraz kreativnosti i želje za zabavom, tradicijska glazba dio je običaja i obreda vezanih uz svakidašnji život i važne događaje u životu svakog pojedinca. Nekada se generacijama prenosila isključivo usmenom predajom. Danas napretkom tehnike, sredstava komunikacije, usavršavanjem metoda poučavanja postaje to sve više zadaća škole. Prema nastavnom planu i programu za osnovnu školu na snazi u Republici Hrvatskoj (2006.) učitelj ima slobodu izbora tradicijskih motiva i napjeva kao i drugih tradicijskih sadržaja koje može uvrstiti u svoj izvedbeni nastavni program. U radu su iskazani podaci o realizaciji takvih sadržaja. U empirijskom istraživanju anketnim upitnikom ispitani su stavovi učitelja nižih razreda osnovne škole južne Istre o zastupljenosti tradicijske glazbe u nastavi Glazbene kulture. Istraživanje je pokazalo različitosti u realizaciji tradicijskih sadržaja uvjetovane u prvom redu osobnim stajalištem učitelja/nastavnika. U očuvanju glazbene baštine suvremeni organizirani odgojno-obrazovni sustav ima neprocjenjivu ulogu. Redovnom nastavom i izvannastavnim aktivnostima uz korelaciju s ostalim područjima učitelji mogu pomoću tradicijske glazbe upotpuniti širinu spoznaja te pridonijeti razvoju učeničkih znanja i vještina.
\end{abstract}

Ključne riječi: tradicijska glazba Istre, nastavni plan i program, Glazbena kultura, učitelji Glazbene kulture

\section{UVODNA PROMIŠLANJA}

Glazbeni identitet naroda poistovjećuje se s glazbenim izričajem koji je narod stvorio, prilagodio svojim potrebama, u njega ugradio specifične spoznaje i vještine i njime se koristio za uspostavljanje odnosa u društvu. Stoljećima njegovan narodni glazbeni jezik oduvijek je bio efikasno sredstvo komunikacije pojedinca i njegovog užeg i šireg okruženja. Isticao je bitna obilježja sredine, identificirao kulturne, psihološke i sociološke aspekte života njenih žitelja te pružao potporu pozicioniranju pojedinca unutar društvene zajednice.

Glazbu čije osobitosti određuje i oblikuje narodni izričaj imenujemo s više nazivlja. Pojmove folklorna, narodna, pučka i zavičajna glazba u novije doba sve češće zamjenjujemo nazivom tradicijska glazba. Svima je zajedničko isticanje povijesnih, društvenih i kulturnih glazbenih obilježja lokaliteta, svojevrsno „glazbeno mikropodručje narodnog izraza“ (Sam Palmić, 2013, str. 560).

Za tradicijsku glazbu (folklornu glazbu) koju vrlo često imenujemo samo skraćenicom folklor (engl. folk, narod i lore, znanje, znanost, predaja), izraženiji interes susrećemo pojavom 
romantizma. Tim se pojmom 1846. godine koristio engleski antikvar William John Thoms, obuhvativši tom riječju skup pučkih običaja, vjerovanja i predaja (Dobrota, 2002). Potrebno je imati na umu da takav naziv zapravo objedinjuje skup međusobno povezanih narodnih izričaja koji zajedno čine tradicijsku (kulturnu) baštinu određenog geografskog područja (Anić, 2007). Te je izričaje narod tijekom vremena stvarao, nadograđivao, brižljivo baštinio i usmenom predajom prenosio mlađim naraštajima. Vjerovanja, priče, poslovice, igre, način odijevanja i ponašanja, umijeće crtanja i slikanja, rezbarenja i oblikovanja, kao i niz glazbenih aktivnosti kojima je kulisa uvijek bio sam životni prostor, glavna su obilježja kulturne baštine u kojoj važno mjesto pripada upravo njezinoj glazbenoj komponenti.

Tradicijska glazba određenog područja izražava specifična obilježja i svojevrsna je refleksija mentaliteta i kulture življenja stanovništva. Toj se glazbi, kao i glazbi uopće, pripisuju svojstva pripovijedanja istinitih i maštovitih sadržaja, opisivanja i tonskog oslikavanja likova i događaja, dočaravanja vremena i prostora, kao i „moć“ kojom djeluje na emocije pojedinca, razvija njegovu maštu i potiče kreativnost. Tom je glazbenom izričaju moguće pripisati i snažan utjecaj koji je tijekom povijesti imao na glazbeno stvaralaštvo uvaženih skladatelja i na razvoj umjetničke glazbe u cijelosti. U melodijskoj, ritmičkoj i harmonijskoj izvornosti tradicijske glazbe mnogi su glazbenici prošlosti tražili i nalazili nadahnuće za svoja umjetnička djela, neovisno o povijesnim i stilskim strujanjima (Chopin, Bartok, Smareglia, Gotovac i mnogi drugi).

\section{TRADICIJSKA GLAZBA ISTRE I NJEZINA OBILEŽA}

Ključnu ulogu u kreiranju i oblikovanju bogate glazbene baštine Istre odigrala su njezina burna povijesna događanja. Neprocjenjiv doprinos očuvanju kulturne baštine, slijedom toga i glazbene, tijekom vremena treba svakako pripisati suživotu i toleranciji naroda teritorijalno uskog i multietničkog, prostora. Stoljetna prisutnost Talijana na priobalnom dijelu Istre vuče korijenje iz doba rimske i mletačke civilizacije (Radole, 1976, str. 81; Matijašić, u Ivetić, 2006, str. 86-87) i jedna je od najstarijih autohtonih narodnosti koja obitava na istarskom poluotoku. Hrvati su Istru počeli naseljavati počevši od VII. stoljeća te s vremenom doprli do rubnih dijelova njene južne i zapadne strane (Budicin u Ivetić, 2006, str. 172-173; 197-198). Tijekom više stoljeća Istra je bila dio Franačke države (VIII. st.) i njome su vladale njemačke feudalne obitelji (X. i XI. st.), a od XII. st. obalni su se gradovi postupno predavali Veneciji. U XVI. i XVII. stoljeću čitav sjeverni dio Istarskog poluotoka, široki pojas kopna na zapadu i čitav južni i jugoistočni dio, dakle tri četvrtine teritorija, bilo je pod vlašću Mletačke Republike, a preostali, centralni dio, bio je od XIV. stoljeća pod vlašću Habsburgovaca (Bertoša, 1978, str. 106).

Kao posljedica povijesnih događanja i društvenih previranja u Istri se i danas dominantno ističu hrvatska i talijanska glazbena tradicija (Marušić, 1995, str. 12). U kontinentalnom dijelu Istre prevladava glazbeni izričaj pretežno hrvatske komponente stanovništva, pjevanje „na tanko i debelo“ i sviranje „u dva“ ili „na dva“ (Veljović, 2005). Vokalna izvedba dvaju po intonaciji različitih glasova (dva muška glasa, muški i ženski glas, rjeđe dvaju ženskih glasova) često je popraćena i zvukom tradicijskih glazbala roženica, od kojih jedna u višoj a druga u nižoj tonskom legi, dupliraju melodiju glasova. Pučki se napjevi oslanjaju na arhaičnu tonsku strukturu i međuintervalski odnos tijesnih intervala poznat pod nazivom istarski tonski niz (iako uobičajen, manje je spretan izraz istarska ljestvica), koji obuhvaća tonsku strukturu od šest po visini različitih tonova (Veljović, 2005).

Naziv istarska ljestvica primjereniji je osmotonskom nizu koji je svojim višegodišnjim proučavanjem i zapisivanjem brojnih melodija i napjeva s terena konstruirao istarski melograf i skladatelj Ivan Matetić-Ronjgov. Takva je ljestvica (osmotonski niz) korištena kao podloga brojnim instrumentalnim i vokalnim skladbama skladanima prema teorijskim okvirima temperiranog ugođaja (Brajša Rašan, Matetić-Ronjgov, Zlatić, Milotti i drugi). 
Srodne tonske strukture susrećemo u djelima Messianea (II modus) i Skrijabina (modus) s nazivom simetrična i oktatonska ljestvica (Veljović, 2005).

Instrumentalna glazba, najčešće plesnog karaktera, izvodi se na arhaičnim glazbalima mihu ili mišnicama, sviralama, šurlama, roženicama (sopelama). Naziv im se mijenja ovisno o mjestu ili području, a njihov originalan, jedinstven timbar uvjetovan je prirodnim materijalom i isključivo ručnom izradom. Stoga govorimo o puhačkim glazbalima osebujnog, netemperiranog ugođaja, čije se porijeklo gubi u dalekim vremenima i hirovitim povijesnim događanjima (Marušić, 1995, str. 88-94).

Za neka su pak glazbala graditelji i približno vrijeme njihove izrade poznati kao i začetak njihove uporabe u glazbenoj praksi žitelja Istre. Mahom su to glazbala srodna glazbalima „umjetničke" glazbe poput: violine, klarineta, violoncella (leron/bajs), usne harmonike (organića), dijatonske harmonike (harmonika trieština) (Marušić, 1995, str. 68-91).

Možemo zaključiti da instrumentalnu praksu na istarskom prostoru po svojoj dugovječnosti i rasprostranjenosti predstavljaju dvije skupine glazbala. Obalni predjeli poluotoka gaje potpuno drugačiji glazbeni izričaj uz napjeve izrazito temperiranog suzvučja, tercnih i sekstnih intervalskih odnosa i uglavnom konsonantnih harmonija. U vokalnoj se glazbi ističu rovinjske bitinade, arie da cuntrada i arie da nuoto, kao i arhaični pučki napjevi a pera i alla longa iz naselja Galižane, nadomak Pule (Starec, 2004; Di Pauli Paulovich, 2012, str. 182-184, Benussi, 2012). lako je na tom prostoru težište na a cappella vokalnoj praksi, u pojedinim naseljima puljštine kao i gradu Vodnjanu ukorijenila se i vokalno instrumentalna glazbena praksa, od kojih je vrijedno istaknuti glazbene primjere villotte i discanti (Donorà, 2003, Starec, 2004).

Tonska struktura napjeva i instrumentalnih melodija, što karakterizira obalne predjele, uvjetuje izbor glazbala poput violine, lerona (prema veličini između violoncella i contrabassa), mandoline, tonski definiranog temperiranog (ugođenog) zvuka. Iznimka su u toj skupini arhaička glazbala pive (glazbalo srodno mihu) i simbolo (membrafon manjih dimenzija opremljen metalnim dodacima) ručne izrade, koja prate glazbena zbivanja u naseljima Galižana i Šišan. Instrumentalna izvedba povremeno prati pjevanje manje skupine ili više pjevača, a najčešće se sve upotpunjuje i plesnim koreografijama (Donorà, 2003, Starec, 1985).

Autohtono pučko pjevanje i sviranje plod su stvaranja darovitih pojedinaca koji su praksom usmene predaje prkosili zaboravu arhaičnih napjeva i instrumentalnih melodija. Tako očuvane darovane su mlađim naraštajima i prenosile se kroz vrijeme sve do trenutka kada je netko to pažljivo, raspoloživim sredstvima i znanjem, zabilježio (Hauser, 2006).

U prilog tomu je i podatak da su u Zagrebu između 1929. i 1940. u cilju promocije istarskog glazbenog izričaja izvan zavičaja istarski emigranti započeli s objavljivanjem mjesečnika, a kasnije tjednika „Istra“, u kojemu je pored književnosti prostor posvećen i osobitostima folklorne glazbe (Miklaušić-Čeran, 2010).

Zaslugu za objavu i promoviranje članaka na ovu temu imali su glazbenici istraživači koji su rezultate svojih istraživanja i zaključna razmišljanja na temu istarskog glazbenog izričaja objavljivali u publikaciji kao i skladatelji/izvođači koji su skladali/izvodili glazbu nadahnuti pučkim napjevima, svirkom i plesom. Zahvaljujući brižljivosti rijetkih entuzijasta glazbene baštine, ovi su napjevi, melodije, glazbala i s njima vezana izvođačka praksa sačuvani od zaborava. Njihovim se neumornim djelovanjem i danas organiziraju smotre i festivali narodne glazbe i plesa prepoznati u Europi i svijetu (Leron u Vodnjanu, Z bajson po Istri u Roču). U prilog tomu govori i podatak da je tradicijska glazba Istre 2009. godine uvrštena na UNESCO-vu listu nematerijalnih spomenika kulture, što samo potvrđuje njenu iznimnu važnost na svjetskoj razini kao i potrebu njenog očuvanja za naredne naraštaje. U tim su nastojanjima školske institucije, svojim nastavnim i izvannastavnim aktivnostima i prema pedagoškim standardima dobro osmišljenim programima, savršeno mjesto promicanja takvih vrijednosti. 


\section{GLAZBENE AKTIVNOSTI U RAZREDNOJ NASTAVI}

Polazeći od toga da je primarni cilj nastave Glazbene kulture u prvim razredima osnovne škole razvijati senzibilitet učenika za glazbu i za glazbene aktivnosti, svako druženje učenika s glazbom trebalo bi rezultirati važnim trenutkom u stjecanju novih spoznaja i vještina. Susret $s$ glazbom pogodovao bi tako stvaranju ugodnog, opuštenog radnog okruženja i ujedno odašiljao snažne refleksije na ostala nastavna područja (Crnčić Brajković, Biasiol Babić, 2010). Ishodi istraživanja upućuju na to da na razvoj djetetovih glazbenih sposobnosti vrlo učinkovito mogu utjecati učitelji primarnog obrazovanja od 1. do 4. razreda osnovne škole (Šulentić Begić, Bubalo, 2014). Susret s glazbom u toj bi se dobnoj skupini trebao primarno zadržati na slušanju glazbe, pjevanju i ritmiziranju jednostavnih pjesama te neizostavno na kretanju uz glazbu. U tom je smislu potrebno istaknuti važno obilježje nastavnog programa u primjeni, koje ističe prednosti otvorenog modela nastave kojim se učitelju/nastavniku dopušta slobodu samostalnog kreiranja nastavnog sata, vodeći pritom računa o željama i potrebama pojedinca kao i raspoloživosti konkretne skupine učenika. Smjernice koje program nastave glazbene kulture daje učiteljima/nastavnicima nižih razreda dotiču se njenih glavnih područja: pjevanje, sviranje, slušanje glazbe i glazbena kreativnost (Nastavni plani i program za osnovnu školu, 2006).

Pjevanje i sviranje usmjereno je razvoju pravilne intonacije i lijepog (ugodnog) vokalnog izražavanja, osjećaja za ritam i metar, te koordinacije pokreta kao osnovnih preduvjeta u realizaciji glazbenih, ali i drugih nastavnih aktivnosti (Nastavni plani i program za osnovnu školu, 2006).

Prema istraživanju Šulentić Begić, provedenom u nižim razredima osnovne škole, pjevanje je pored slušanja glazbe najzastupljenija glazbena aktivnost. U rezultatima svojega istraživanja autorica navodi kako omiljenost te aktivnosti opada s fiziološkim promjenama u mutaciji glasa, u prvom redu zbog osjećaja nelagode učenika i poteškoćama u intonaciji (Šulentić-Begić, 2010). Kao rezultat istraživanja otkriva se da za aktivnosti pjevanja učitelji uglavnom slijede pjesme propisane planom i programom, ali koriste i mogućnosti koje im plan i program nudi glede njihovog slobodnog izbora (Radičević, Šulentić-Begić, 2010).

Slušanje glazbe odnosi se primarno na aktivno slušanje kojemu je cilj razvoj slušne koncentracije, glazbenog pamćenja i prepoznavanja temeljnih osobina zvuka (ljudskog glasa, glazbala). Aktivno slušanje omogućuje učenicima opažanje i razlikovanje izvođača, a diskusija i razgovor potiču razvoj kritičkog razmišljanja.

U svim nastavnim područjima ključan je motivacijski učinak koji bi glazba u konačnici svakome i trebala pružiti. Jačanjem senzibiliteta za ovo područje jačat će potreba učenika za glazbenim aktivnostima u školi ali i izvan nje, poticat će se njihova maštovitost i jačati osjećaj samopouzdanja, što su dobre osnove u izražavanju glazbene kreativnosti.

\section{TRADICIJSKA GLAZBA U NASTAVI GLAZBENE KULTURE: KORELACIJE, PROBLEMI I PERSPEKTIVE}

Imajući u vidu da se dijete prije dolaska u školu rijetko susreće s tradicijskom glazbom, osim ponekad na javnim mjestima u svom okruženju, zadaća je učitelja uključiti ovu glazbu u organizirani nastavni proces i uz primjere razgovorom otkrivati njezine kvalitete.

Uvođenje učenika u svijet tradicijske glazbe životnog okruženja programom Glazbene kulture pruža učitelju razredne nastave brojne mogućnosti korelacije s nastavnim sadržajima ostalih predmeta. U nižim razredima glazba i igra prožimaju sve školske aktivnosti i mogu se povezati sa svim nastavnim područjima.

Proces prezentiranja ove glazbe, njenih osobitosti i značenja u životu naroda ovog kraja, njene svjetovne i religijske note, njenog utjecaja na izbor aktivnosti i životnih navika žitelja i 
konačno njena postojanost tijekom vremena, pružaju učeniku vrijedne spoznaje iznimno korisne pri vrednovanju tog glazbenog izričaja.

Pojmovi vezani za tradicijsku glazbu često su vezani za specifičnost narječja određenog područja. Živopisnost dijalekta u principu ne prati promjene koje proživljava standardni jezik i stoga pojedine riječi pa i čitave rečenice naprosto odumiru ili se koriste samo u uskom krugu obitelji. Učenje pojmova izraženih dijalektom u tom će slučaju biti ishod tematski osmišljene glazbene aktivnosti koja će, dopunjena primjerenom diskusijom, konkretnim primjerima i razgovorom, pridonijeti izvođenju zaključaka o nekadašnjem životu i radu ljudi u zavičaju. Usvojeni pojmovi mogu se povezati s geografskim i povijesnim sadržajima o Istarskoj županiji koji se obrađuju u trećem razredu osnovne škole.

Organizirano i sistematično institucionalno poučavanje može znatno pridonijeti dodatnoj popularizaciji ove glazbe. Bogatstvo sadržaja na temu tradicijske glazbe pruža široke mogućnosti izbora. Dojmljive su glazbene igre i brojalice kojima uz dodatak jednostavnih pokreta učenik istodobno razvija pjevačku sposobnost, govorne i motoričke vještine. Takva iskustva kod učenika jačaju samopouzdanje, utječu na razvoj socijalnih vještina što je iznimno važno kod aktivnosti u skupini. Pjevanjem pučkih napjeva, poput dječjih brojalica, božićnih i drugih pjesama, učenik doživljava glazbu i njenu osnovnu poruku, razvija senzibilitet prema tradicijskoj pjesmi i aktivnosti pjevanja. Podupiranjem učenika u pjevanju brojalica, slušanju zvuka pojedinih glazbala i melodija otvara se mogućnost stjecanja vrijednih glazbenih iskustava, koje treba dopuniti ritmičkim pokretima kako bi se upotpunila sinergija cjelovite aktivnosti. Potrebno je upoznati učenike s elementima glazbenog jezika, poticati individualne i kolektivne aktivnosti pjevanja, sviranja i slušanja uz ritmičke pokrete ili plesne korake. Tome treba dodati i važnost organiziranja zanimljivih aktivnosti uz opuštajuću i vedru atmosferu koja neće rezultirati opterećenjem, već će u učeniku probuditi želju za sudjelovanjem.

Svjesno vrednovanje osobitosti tradicijske glazbe potiče učenike na razvoj osobnog, kritičkog i estetskog stava prema ovoj vrsti glazbe, jača potrebu za usporedbom s drugim i drugačijim kulturama, te glazbom uopće. Poznavanje osobitosti ovog glazbenog izričaja pomoći će učeniku u odabiru njemu najzanimljivijeg oblika glazbene aktivnosti te poticati njegovu maštovitost i kreativnost. Tako, na primjer već usvojene melodijske i ritmičke strukture mogu biti osnova za dodavanje novog teksta ili postojeća pjesma na dijalektu za stvaranje melodijske strukture.

Dakle, tradicijska glazba nudi široke i bogate mogućnosti prezentacije sadržaja i korelacije s ostalim odgojno-obrazovnim područjima: priroda i društvo, hrvatski jezik i književnost, tjelesna i zdravstvena kultura, likovna kultura i dr.

Radi što kvalitetnije i zanimljivije prezentacije osobitosti istarske tradicijske glazbe, na raspolaganju nam stoje brojni tonski zapisi koji su dio arhivske građe fonoteka radijskih postaja, Sveučilišne knjižnice u gradu Puli, Povijesnoga i Državnoga arhiva Istre. Poseban je naglasak svakako na aktivnom, neposrednom susretu s ovom glazbom na raznim smotrama i festivalima koji se organiziraju diljem regije. Poželjno bi bilo da učitelji i učenici prate, a po mogućnosti i sudjeluju u tim događanjima koji se često organiziraju radi promocije i očuvanja ove glazbe. Sudjelovanje na smotrama i festivalima moglo bi motivirajuće djelovati na učenike u stvaranju pozitivnog odnosa prema tradicijskoj glazbi njihove sredine.

Međutim, istraživanja pokazuju da je prisutnost tradicijskih napjeva u glazbenim aktivnostima vrlo šaroliko raspoređena, a odnos učitelja i učenika prema pjevanju tradicijskih pjesama različit. Naime, uključivanje tradicionalne glazbe u nastavne sadržaje ne nailazi uvijek na odobravanje. Neki se glazbeni pedagozi tome protive jer to nije glazba uz koju djeca danas odrastaju. Među poznatim glazbenim pedagozima u prošlosti za tradicijsku glazbu u nastavi glazbene kulture zalagao se Zoltan Kodaly (prema Pace, 2012, str. 39). On smatra da s glazbenim odgojem treba započeti vrlo rano, koristeći se tradicijskom glazbom jer je ona djetetu najbliža, pomaže u shvaćanju samog sebe, vlastitih korijena, pozitivno djeluje u procesu stvaranja osob- 
nog identiteta i potiče razvoj osjećaja pripadnosti. No u današnjem globalizacijskom svijetu učenici slušaju brojne druge vrste glazbe pa ne čude rezultati istraživanja koje su Radičević i Šulentić Begić provele 2010. u Osnovnoj školi Franje Krežme u Osijeku s učenicima od 1. do 3. razreda, iz kojih se doznaje da je interes za pjevanje narodnih pjesama obeshrabrujuće nizak (Radičević, Šulentić-Begić, 2010). To nas potiče na razmišljanje kako bi u cilju očuvanja tradicijske glazbe svakom učitelju trebalo preporučiti da tradicijske pjesme svakako uvrsti u rad s učenicima mlađe dobi.

\section{CIU, METOdolOGIJA, REZULTATI ISTRAŽIVANJA I RASPRAVA}

\section{Cilj istraživanja}

U ovom istraživanju krenuli smo od teorijskih razmišljanja o važnosti poučavanja tradicijske glazbe u suvremenoj školi. Cilj istraživanja bio je istražiti zastupljenost istarske tradicijske glazbe u nastavi Glazbene kulture u nekoliko škola Istarske županije u Hrvatskoj.

\section{Problemi istraživanja}

- Utvrditi stavove učitelja o zastupljenosti istarske tradicijske glazbe u redovitim nastavnim aktivnostima, u izvannastavnim, slobodnim i izvanškolskim aktivnostima škole u kojoj rade;

- Ispitati stavove učitelja o njihovom praćenju događanja vezanih za istarsku tradicijsku glazbu;

- Utvrditi stavove učitelja o zastupljenosti istarske tradicijske glazbe u njihovim nastavnim aktivnostima;

- Utvrditi stavove učitelja o zastupljenosti pjevanja tradicijskih pjesama, sviranja tradicijskih instrumenata i tradicijskog plesa u njihovim nastavnim aktivnostima;

- Ispitati stavove učitelja o korištenju udžbenika, nosača zvuka i videosnimaka u vlastitom predstavljanju istarske tradicijske glazbe;

- Ispitati mišljenje učitelja o organizaciji aktivnosti usmjerenih na očuvanje istarske tradicijske glazbe u njihovoj školi;

- Ispitati mišljenje učitelja o važnosti poticanja učenika na poštivanje tradicijske glazbe okruženja (zavičaja) u kojem žive.

\section{Metodologija istraživanja i podaci o ispitanicima}

Korištene istraživačke metode jesu deskriptivna i kauzalno-neeksperimentalna metoda pedagoškog istraživanja (Mužić, 2004) s postupcima anketiranja i procjene stavova. Za postupak anketiranja kao instrument prikupljanja podataka konstruiran je upitnik u koji su uvrštene tvrdnje o prisutnosti tradicijske glazbe u redovitim i izvannastavnim aktivnostima iz predmeta Glazbena kultura, o načinima uključenosti tradicijske glazbe u školske aktivnosti i važnosti te glazbe u odgojno-obrazovnom procesu. Istraživanje je provedeno u proljeće 2017. godine, a od ispitanika se tražilo da izraze svoje mišljenje, koristeći se ponuđenim skalama Likertovog tipa od 4 stupnja ( 1 = uopće ne, 2 = malo, 3 = osrednje, 4 = puno).

Upitnici su primijenjeni na ciljanom uzorku u čijem je sastavu bilo ukupno 87 učitelja (97\% ženskog spola) osnovnih škola s nastavom na hrvatskom, odnosno talijanskom jeziku u Istri. $U$ istraživanje su uključeni učitelji razredne nastave i učitelji glazbene kulture koji predaju Glazbenu kulturu u četvrtom razredu osnovne škole. Od toga 48 ispitanika su učitelji razredne nastave i glazbene kulture u školama s nastavom na hrvatskom jeziku, a 39 učitelji razredne nastave i glazbene kulture s nastavom na talijanskom jeziku. Svim ispitanicima osigurana je povjerljivost pri upotrebi njihovih osobnih podataka te je ispunjavanje upitnika bilo anonimno u smislu da se nisu tražila imena i prezimena ispitanika. 


\section{Rezultati istraživanja i rasprava}

Podatke smo statistički obradili u skladu s ciljevima i zadacima istraživanja uz pomoć statističkog programskog paketa SPSS za Windows, na razini deskriptivne i inferencijalne statistike. Kvantitativno izraženi podaci obrađeni su pomoću sljedećih statističkih postupaka: postotak, aritmetička sredina, standardna devijacija i t-test.

Iz tablice br. 1 vidljivo je da skoro polovica $(44,8 \%)$ ispitanika tvrdi kako su sadržaji iz tradicijske glazbe Istre malo prisutni u nastavnim aktivnostima njihovih škola, $36,8 \%$ tvrdi da su osrednje prisutni, a samo $11,5 \%$ njih tvrdi da je tradicijska glazba puno zastupljena. Stav prema uključivanju tradicijske glazbe u nastavne sadržaje ne nailazi uvijek na odobravanje. Neki se učitelji tome protive jer smatraju da to nije glazba koja je današnjoj djeci prirasla srcu odmalena, a nema ni nekadašnju funkciju praćenja svakidašnjih aktivnosti. Drugi su pak uvjereni da je tradicijska glazba djetetu najbliža, razvija mnoge vještine, pomaže u shvaćanju vlastitih korijena te pozitivno djeluje u procesu stvaranja osobnog identiteta i osjećaja pripadnosti socijalnoj zajednici. S obzirom na utvrđene pozitivne strane uključivanja tradicijske glazbe u nastavne aktivnosti, dobiveni rezultati su porazni.

Tablica 1: Mišljenje ispitanika o zastupljenosti istarske tradicijske glazbe u školskim aktivnostima

\begin{tabular}{|l|c|c|c|c|c|}
\hline \multicolumn{1}{|c|}{$\begin{array}{c}\text { Zastupljenost istarske tradicijske glazbe u školskim } \\
\text { aktivnostima }\end{array}$} & $\mathbf{N}$ & $\begin{array}{c}\text { uopće } \\
\text { ne } \%\end{array}$ & $\begin{array}{c}\text { malo } \\
\%\end{array}$ & $\begin{array}{c}\text { osrednje } \\
\%\end{array}$ & $\begin{array}{c}\text { puno } \\
\%\end{array}$ \\
\hline $\begin{array}{l}\text { Zastupljenost istarske tradicijske glazbe u redovitim } \\
\text { nastavnim aktivnostima škole }\end{array}$ & 86 & 5,7 & 44,8 & 36,8 & 11,5 \\
\hline $\begin{array}{l}\text { Zastupljenost istarske tradicijske glazbe u izvannastavnim } \\
\text { aktivnostima škole }\end{array}$ & 87 & 5,7 & 36,8 & 41,4 & 16,1 \\
\hline $\begin{array}{l}\text { Uključenost učenika u slobodne aktivnosti vezane uz istarsku } \\
\text { tradicijsku glazbu }\end{array}$ & 87 & 25,3 & 34,5 & 32,2 & 8,0 \\
\hline $\begin{array}{l}\text { Uključenost učenika u izvanškolske aktivnosti vezane uz } \\
\text { istarsku tradicijsku glazbu }\end{array}$ & 87 & 29,9 & 48,3 & 17,2 & 4,6 \\
\hline Praćenje događanja vezanih uz istarsku tradicijsku glazbu & 87 & 17,4 & 46,5 & 31,4 & 4,7 \\
\hline $\begin{array}{l}\text { Zastupljenost istarske tradicijske glazbe u glazbenim } \\
\text { aktivnostima ispitanika }\end{array}$ & 87 & 5,7 & 51,7 & 39,1 & 3,4 \\
\hline $\begin{array}{l}\text { Zastupljenost istarskog tradicijskog plesa u glazbenim } \\
\text { aktivnostima ispitanika }\end{array}$ & 87 & 5,8 & 26,7 & 45,3 & 22,1 \\
\hline $\begin{array}{l}\text { Zastupljenost sviranja istarskih tradicijskih instrumenata u } \\
\text { glazbenim aktivnostima ispitanika }\end{array}$ & 86 & 29,9 & 34,5 & 23,0 & 11,5 \\
\hline $\begin{array}{l}\text { Zastupljenost pjevanja istarskih tradicijskih pjesama u } \\
\text { glazbenim aktivnostima ispitanika }\end{array}$ & 87 & 5,7 & 19,5 & 31,0 & 43,7 \\
\hline $\begin{array}{l}\text { Korištenje udžbenika u predstavljanju istarske tradicijske } \\
\text { glazbe }\end{array}$ & 87 & 27,9 & 44,2 & 22,1 & 5,8 \\
\hline $\begin{array}{l}\text { Korištenje nosača zvuka (CD-a) u predstavljanju istarske } \\
\text { tradicijske glazbe }\end{array}$ & 87 & 8,0 & 18,4 & 31,0 & 42,5 \\
\hline $\begin{array}{l}\text { Korištenje videosnimki u predstavljanju istarske tradicijske } \\
\text { glazbe }\end{array}$ & 85 & 27,6 & 29,9 & 21,8 & 18,4 \\
\hline $\begin{array}{l}\text { Organizacija aktivnosti usmjerenih na očuvanje istarske } \\
\text { tradicijske glazbe u školi ispitanika }\end{array}$ & 87 & 13,8 & 40,2 & 31,0 & 14,9 \\
\hline $\begin{array}{l}\text { Mišljenje ispitanika o važnosti poticanja učenike na } \\
\text { poštivanje tradicijske glazbe okruženja (zavičaja) u kojem žive }\end{array}$ & 87 & - & 2,3 & 20,7 & 77,0 \\
\hline
\end{tabular}


Malo bolji rezultati dobiveni su za tvrdnju o prisutnosti tradicijske glazbe Istre u izvannastavnim aktivnostima. $36,8 \%$ ispitanika smatra da je ta glazba malo zastupljena u izvannastavnim aktivnostima njihove škole, $41,4 \%$ smatra da je osrednje zastupljena, a $16,1 \%$ da je puno zastupljena. U nekim školama djeluju folklorne grupe koje su prisutne i obogaćuju svojim nastupom sve važnije priredbe, manifestacije i svako javno društveno djelovanje svojih škola.

Što se tiče uključenosti učenika u slobodne aktivnosti vezane uz istarsku tradicijsku glazbu, 25,3\% ispitanih učitelja izjavilo je da učenici nisu uopće uključeni u takve aktivnosti, 34,5\% tvrdi da su malo uključeni, $32,2 \%$ da su osrednje uključeni, a $8 \%$ da su puno uključeni. I u ovom slučaju rezultati vjerojatno ovise o školama gdje ispitanici rade, odnosno o tome postoje li u njihovoj školi slobodne aktivnosti koje učenici mogu odabrati, a njeguju očuvanje tradicijske glazbe bilo pjevanjem, sviranjem tradicionalnih instrumenata ili plesom.

Za tvrdnju o uključenosti učenika u izvanškolske aktivnosti vezane uz istarsku tradicijsku glazbu dobiveni rezultati još su lošiji od prethodnih. 29,9\% ispitanika izjavilo je da učenici nisu uopće uključeni u izvanškolske aktivnosti vezane uz istarsku tradicijsku glazbu, 48,3\% da su malo uključeni, $17,2 \%$ da su osrednje uključeni, a $4,6 \%$ da su puno uključeni. $S$ obzirom da učitelji vode brigu o izvanškolskim aktivnostima učenika, njihove se izjave temelje na pouzdanim informacijama pa su prema tome prihvatljiv indikator niske uključenosti učenika u folklorne i slične grupe koje gaje istarsku tradicijsku glazbu.

Nadalje, dobiveni rezultati pokazuju da ispitanici nisu baš skloni praćenju događanja vezanih uz istarsku tradicijsku glazbu kao što su smotre, koncerti i susreti folklornih skupina, radionice tradicijskog plesa i sl. Iz rezultata u tablici br. 1 vidljivo je da ih uopće ne prati 17,4\% ispitanih učitelja, $46,5 \%$ ih malo prati, $31,4 \%$ ih osrednje prati, a samo $4,7 \%$ ih prati puno.

O zastupljenosti istarske tradicijske glazbe u glazbenim aktivnostima ispitanih učitelja, $51,7 \%$ njih je izjavilo da su te aktivnosti malo prisutne u njihovim glazbenim aktivnostima, $39,1 \%$ je izjavilo da su osrednje prisutne, a samo $3,4 \%$ da su puno prisutne. Osim odabira tradicijske glazbe u redovitim nastavnim aktivnostima iz Glazbene kulture, učitelj može izabrati i ponuditi učenicima slobodne aktivnosti (npr. zbor, ples, sviranje) u koje ugraditi tradicijske sadržaje (Nastavni plan i program za osnovnu školu, 2006, str. 66). Rezultati istraživanja pokazuju da je tradicijski ples malo $(26,7 \%)$ ili osrednje $(45,3 \%)$ zastupljen u glazbenim aktivnostima ispitanika. Samo njih $21,1 \%$ puno uključuje tradicijski ples u svoje glazbene aktivnosti. U odnosu na tradicijski ples, sviranje tradicionalnih instrumenata još je manje zastupljeno u glazbenim aktivnostima ispitanika, odnosno $29,9 \%$ ispitanika izjavilo je da uopće nije prisutno, 34,5\% njih tvrdi da je malo zastupljeno, $23 \%$ osrednje, a samo $11,5 \%$ ispitanika izjavilo je da je sviranje puno zastupljeno (tabl. 1) u njihovim glazbenim aktivnostima. U odnosu na ples i sviranje pjevanje tradicijskih pjesama najviše je zastupljeno u nastavnim aktivnostima ispitanika. Prema dobivenim podacima $43,7 \%$ ispitanika tvrdi da je puno zastupljeno, $31 \%$ njih tvrdi da je osrednje prisutno, dok samo 19,5\% ispitanika tvrdi da je malo zastupljeno, a 5,7\% njih da uopće nije zastupljeno (tab. 1). Pjevanje je glazbena aktivnost dostupna svima i vrlo omiljena među učenicima te se izjave ispitanih učitelja slažu s rezultatima drugih istraživanja, ali ne u području pjevanja tradicijskih pjesama.

Što se tiče korištenja medija u predstavljanju istarske tradicijske glazbe (tab. 1), 27,9 \% ispitanika izjavilo je da uopće ne koristi udžbenik, 44,2\% njih ga malo koristi, 22,1 \% ga osrednje koristi, a samo 5,8\% njih ga puno koristi. Takav stav je razumljiv jer udžbenik iz Glazbene kulture mora biti prilagođen potrebama svih učenicika u Hrvatskoj, ali samim time ne može opširno prezentirati sadržaje iz tradicijske glazbe specifične za svaku pojedinu geografsko-kulturnu regiju u Republici. Mnogo se više koristi nosač zvuka (CD) radi svoje široke rasprostranjenosti i jednostavne uporabe. Naime, $42,5 \%$ ispitanika tvrdi da ga puno koristi, $31 \%$ osrednje, $18,4 \%$ da ga malo koristi, a $8 \%$ ga uopće ne koristi. U predstavljanju istarske tradicijske glazbe $27,6 \%$ ispitanika izjavilo je da uopće ne koristi videosnimke, 29,9\% da ih malo koristi, $21,8 \%$ da ih koristi osrednje, a $18,4 \%$ da ih koristi puno. S obzirom na dostupnost videosnimki (dvd, internet) i 
njihovu atraktivnost kao medija koji ujedinjuje sliku, zvuk i riječ, taj se medij premalo koristi.

Iz podataka u tablici br. 1 vidljivo je također da se prema mišljenju 40,2\% ispitanika u školama malo organiziraju aktivnosti usmjerene na očuvanje istarske tradicijske glazbe. Njih $13,8 \%$ misli da se takve aktivnosti uopće ne organiziraju, $31 \%$ da se osrednje organiziraju, a samo $14,9 \%$ da se puno organiziraju. I ti rezultati vjerojatno ovise o školama, neke su na tom području aktivnije od drugih.

Posljednji rezultati prikazani u tablici br. 1 pokazuju da su ispitanici svjesni važnosti očuvanja tradicijske glazbe i približavanja učenika kulturnom blagu okruženja u kojem žive i odrastaju. Čak $77 \%$ ispitanika smatra jako važnim poticati učenike na poštivanje tradicijske glazbe zavičaja u kojem žive. Međutim nisu svjesni da je sačuvati kulturnu baštinu zavičaja i prenositi ju mlađima, zadaća u prvom redu škola i ostalih obrazovnih institucija, jer joj inače prijeti zaborav. Stoga bi svaki učitelj trebao osvijestiti važnost svoje uloge u procesu očuvanja lokalne kulturne baštine.

$\mathrm{U}$ tablici br. 2. prikazani su rezultati testiranja značajnosti razlika u procjenama dviju skupina ispitanika, učitelja nižih razreda u hrvatskim i učitelja u talijanskim osnovnim školama južne Istre, koje se odnose na njihovo mišljenje o zastupljenosti istarske tradicijske glazbe u školskim aktivnostima. Analiza je provedena t-testom prema kojem postoje statistički značajne razlike na razini pouzdanosti od $p<.05$ samo za mali broj varijabli. Analiza aritmetičkih sredina pokazuje da se u većini tvrdnji učitelji hrvatskih i talijanskih škola slažu da je istarska tradicijska glazba malo zastupljena u školskim aktivnostima, malo se prate događanja vezana uz istu i organiziraju aktivnosti u cilju njezinog očuvanja, iako smatraju važnim poticati učenike na poštivanje i očuvanje zavičajne tradicijske glazbe.

Tablica 2: Rezultati analize t-testa stavova ispitanih učitelja hrvatskih i talijanskih osnovnih škola o zastupljenosti tradicijske glazbe u nastavi glazbene kulture

\begin{tabular}{|c|c|c|c|c|c|}
\hline $\begin{array}{l}\text { Zastupljenost istarske tradicijske glazbe u } \\
\text { školskim aktivnostima }\end{array}$ & Ispitani učitelji & M & SD & $\mathbf{t}$ & $\mathbf{p}$ \\
\hline $\begin{array}{l}\text { Zastupljenost istarske tradicijske glazbe u } \\
\text { nastavnim aktivnostima škole }\end{array}$ & $\begin{array}{l}\text { hrvatske škole } \\
\text { talijanske škole }\end{array}$ & $\begin{array}{l}2.60 \\
2.47\end{array}$ & $\begin{array}{l}.76 \\
.79\end{array}$ & - & - \\
\hline $\begin{array}{l}\text { Zastupljenost istarske tradicijske glazbe u } \\
\text { izvannastavnim aktivnostima škole }\end{array}$ & $\begin{array}{l}\text { hrvatske škole } \\
\text { talijanske škole }\end{array}$ & $\begin{array}{l}2.85 \\
2.46\end{array}$ & $\begin{array}{l}.77 \\
.82\end{array}$ & $\begin{array}{c}2.9 \\
2\end{array}$ & $\begin{array}{c}0.0 \\
2\end{array}$ \\
\hline $\begin{array}{l}\text { Uključenost učenika u slobodne aktivnosti vezane } \\
\text { uz istarsku tradicijsku glazbu }\end{array}$ & $\begin{array}{l}\text { hrvatske škole } \\
\text { talijanske škole }\end{array}$ & $\begin{array}{l}2.39 \\
2.02\end{array}$ & $\begin{array}{l}.93 \\
.87\end{array}$ & - & - \\
\hline $\begin{array}{l}\text { Uključenost učenika u izvanškolske aktivnosti } \\
\text { vezane uz istarsku tradicijsku glazbu }\end{array}$ & $\begin{array}{l}\text { hrvatske škole } \\
\text { talijanske škole }\end{array}$ & $\begin{array}{l}2.04 \\
1.87\end{array}$ & $\begin{array}{l}.89 \\
.69\end{array}$ & - & - \\
\hline $\begin{array}{l}\text { Praćenje događanja vezanih uz istarsku tradicijsku } \\
\text { glazbu }\end{array}$ & $\begin{array}{l}\text { hrvatske škole } \\
\text { talijanske škole }\end{array}$ & $\begin{array}{l}2.37 \\
2.05\end{array}$ & $\begin{array}{l}.70 \\
.86\end{array}$ & - & - \\
\hline $\begin{array}{l}\text { Zastupljenost istarske tradicijske glazbe u } \\
\text { glazbenim aktivnostima ispitanika }\end{array}$ & $\begin{array}{l}\text { hrvatske škole } \\
\text { talijanske škole }\end{array}$ & $\begin{array}{l}2.43 \\
2.49\end{array}$ & $\begin{array}{l}.50 \\
.81\end{array}$ & - & - \\
\hline $\begin{array}{l}\text { Korištenje udžbenika u predstavljanju istarske } \\
\text { tradicijske glazbe }\end{array}$ & $\begin{array}{l}\text { hrvatske škole } \\
\text { talijanske škole }\end{array}$ & $\begin{array}{l}2.34 \\
1.71\end{array}$ & $\begin{array}{l}.78 \\
.82\end{array}$ & $\begin{array}{c}3.5 \\
6\end{array}$ & $\begin{array}{c}0.0 \\
0\end{array}$ \\
\hline $\begin{array}{l}\text { Korištenje nosača zvuka (CD-a) u predstavljanju } \\
\text { istarske tradicijske glazbe }\end{array}$ & $\begin{array}{l}\text { hrvatske škole } \\
\text { talijanske škole }\end{array}$ & $\begin{array}{l}3.31 \\
2.79\end{array}$ & $\begin{array}{c}.74 \\
1.13\end{array}$ & $\begin{array}{c}2.5 \\
6\end{array}$ & $\begin{array}{c}0.0 \\
1\end{array}$ \\
\hline $\begin{array}{l}\text { Zastupljenost istarskog tradicijskog plesa u } \\
\text { glazbenim aktivnostima ispitanika }\end{array}$ & $\begin{array}{l}\text { hrvatske škole } \\
\text { talijanske škole }\end{array}$ & $\begin{array}{l}2.87 \\
2.79\end{array}$ & $\begin{array}{l}.79 \\
.89\end{array}$ & - & - \\
\hline $\begin{array}{l}\text { Zastupljenost sviranja istarskih tradicijskih } \\
\text { instrumenata u glazbenim aktivn. ispitanika }\end{array}$ & $\begin{array}{l}\text { hrvatske škole } \\
\text { talijanske škole }\end{array}$ & $\begin{array}{l}2.27 \\
2.02\end{array}$ & $\begin{array}{c}1.03 \\
.93\end{array}$ & - & - \\
\hline $\begin{array}{l}\text { Zastupljenost pjevanja istarskih tradicijskih } \\
\text { pjesama u glazbenim aktivnostima ispitanika }\end{array}$ & $\begin{array}{l}\text { hrvatske škole } \\
\text { talijanske škole }\end{array}$ & $\begin{array}{l}3.12 \\
3.12\end{array}$ & $\begin{array}{l}1.00 \\
.83\end{array}$ & - & - \\
\hline
\end{tabular}




\begin{tabular}{|l|c|c|c|c|c|}
\hline Organizacija aktivnosti usmjerenih na očuvanje & hrvatske škole & 2.66 & .72 & 2.2 & 0.0 \\
istarske tradicijske glazbe u školi ispitanika & talijanske škole & 2.23 & 1.06 & 6 & 2 \\
\hline Mišljenje ispitanika o važnosti poticanja učenike na & hrvatske škole & 3.83 & .43 & - & - \\
poštivanje tradicijske glazbe okruženja (zavičaja) u & talijanske škole & 3.64 & .54 & & \\
kojem žive & & & & & \\
\hline
\end{tabular}

Prema t-testu postoje statistički značajne razlike u tvrdnjama koje se odnose na Zastupljenost istarske tradicijske glazbe $u$ izvannastavnim aktivnostima škole $(\mathrm{t}=2.92 ; \mathrm{p}<.02)$, Korištenje udžbenika u predstavljanju istarske tradicijske glazbe $(\mathrm{t}=3.56 ; \mathrm{p}<.00)$, Korištenje $C D-a$ u predstavljanju istarske tradicijske glazbe $(\mathrm{t}=2.56$; $\mathrm{p}<.01)$ i Organizaciju aktivnosti usmjerenih na očuvanje istarske tradicijske glazbe $u$ školi ispitanika $(\mathrm{t}=2.26 ; \mathrm{p}<.02)$.

Ispitani učitelji iz hrvatskih škola procijenili su malo višu razinu zastupljenosti istarske tradicijske glazbe u izvannastavnim aktivnostima škole i učestaliju organizaciju aktivnosti usmjerenih na očuvanje istarske tradicijske glazbe u njihovim školama u odnosu na ispitanike zaposlene u talijanskim osnovnim školama. Iz dobivenih rezultata također je moguće zaključiti da ispitanici iz hrvatskih škola češće koriste udžbenike i CD-e u predstavljanju istarske tradicijske glazbe u odnosu na učitelje iz talijanskih osnovnih škola. Dobiveni rezultati upućuju na potrebu animiranja učitelja u cilju prenošenja glazbene baštine Istre na mlade naraštaje, posebno učitelja u talijanskim osnovnim školama kojima bi trebalo osigurati i odgovarajuća nastavna sredstva.

\section{ZAKLUČAK}

U teorijskom dijelu rada utvrđeno je da uz redovite i izvannastavne aktivnosti te korelaciju s ostalim nastavnim područjima teme tradicijske glazbe mogu upotpuniti širinu učenikovih spoznaja i pridonijeti razvoju brojnih vještina. Iz rezultata istraživanja, međutim, moguće je zaključiti da je tradicijska glazba u školama južne Istre malo zastupljena. Jedan od uzroka može biti blago neodobravanje učitelja i roditelja te u manjoj mjeri otpor učenika prema zastarjelosti takve glazbe, odnosno njihova potreba za uvođenjem aktualnijih tema. Ispitani učitelji svjesni su važnosti očuvanja tradicijske glazbe i približavanja učenika kulturnom blagu okruženja u kojem žive i odrastaju, ali su nedovoljno svjesni da je sačuvati kulturnu baštinu zavičaja i prenositi ju mlađima zadaća u prvom redu škola i ostalih obrazovnih institucija te da je njihova uloga u tom procesu nezamjenjiva.

\section{LITERATURA}

Agazzi, A. (1989). Infanzia e educazione. U: Heuss, N., Musica e movimento. Brescia: La Scuola. Anić, V. (2007). Rječnik hrvatskoga jezika. Zagreb: Novi liber d.o.o.

Benussi, V. (2012). La storia delle bitinade rovignesi attraverso la raccolta dei testi e delle musiche / Povijest rovinjskih bitinada kroz zbirke stihova i glazbi, Rovigno - Rovinj: Comunità degli Italiani della Città di Rovigno / Zajednica Talijana grada Rovinja.

Bertoša, M. (1978). Neki povijesni i statistički podaci o demografskim kretanjima u Istri u XVI. i XVII. stoljeću. Journal of the Institute of Croatian History, Vol 11, No. 1, 1978, str. 103-129.

Budicin, M. (2006). II Medioevo (538-1420). U: Ivetić, E., (a cura di), (2006). L'Istria nel tempo. Centro di ricerche storiche di Rovigno, Collana degli Atti n.26. Rovigno: Unione Italiana - Fiume, Università Popolare di Trieste, str. 153-265. 
Crnčić-Brajković, M.; Biasiol Babić, R., (2010). Slavko Zlatić: a composer between integration teaching days and inclusion, Metodički obzori, časopis za odgojno-obrazovnu teoriju i praksu, Vol.5, No.10, Sveučilište Jurja Dobrile, Pula, str. 95-110

Crnčić-Brajković, M.; Biasiol Babić, R.; Brajković, M., (2016). Cantilene, giochi musicali e filastrocche, produzioni dialettali per l'infanzia: patrimonio da salvaguardare, 8. međunarodni znanstveni skup „Iz istarske glazbene riznice“, Novigrad: Katedra čakavskog sabora, (objava u tijeku).

Di Paoli Paulovich, D. (2012). Musica e canti d'espressione popolare di area latino-veneta in Istria e Zara. Generi vocali e bibliografia. Histria, 2, 2012, str. 173-203.

Dobrota, S. (2002). Prezentiranje glazbene baštine u prvim razredima osnovne škole, U: Bacalja, R. (ur.), Zbornik radova sa znanstveno-stručnog skupa Živa baština, Zadar: Sveučilište u Splitu, Visoka učiteljska škola u Zadru, str. 135-143.

Donorà, L. (2003). Danze, canzoni, inni e laudi popolari dell'Istria, di Fiume e Dalmazia. Trieste: Istituto Regionale per la Cultura Istriano-fiumano-dalmata, Università Popolare.

Hauser, M. (2006). Usmena predaja kao komunikacijski izazov u obrazovanju. Stare božićne pjesme u Istri, U: Kadum,V. (ur.), Zbornik radova, Međunarodni znanstveni i stručni skup, Pula: Sveučilište u Rijeci, Visoka učiteljska škola u Puli, str. 395-405.

Ivetić, E. (a cura di), (2006). L'Istria nel tempo. Centro di ricerche storiche di Rovigno, Collana degli Atti n.26. Rovigno: Unione Italiana - Fiume, Università Popolare di Trieste.

Marušić, D. (1995). Piskaj, sona, sopi, Pola: Castropola.

Matijašić, R. (2006). L'età romana (177 a.C. - 538 d.C.), U: Ivetić, E., (a cura di), (2006). L'Istria nel tempo. Centro di ricerche storiche di Rovigno, Collana degli Atti n.26. Rovigno: Unione Italiana Fiume, Università Popolare di Trieste, str.71-152.

Miklaušić-Ćeran, S. (2010). Istra i istarski skladatelji u glazbenome životu Zagreba, U: Gortan Carlin, I., P. (ur.), Zbornik radova sa 6. međunarodnog muzikološkog skupa „Iz istarske glazbene riznice“ Ruralna i urbana glazba istarskog poluotoka, Katedra Čakavskog sabora za glazbu, str.103-120.

Mužić, V. (2004). Uvod u metodologiju istraživanja odgoja i obrazovanja. Zagreb: Educa.

Nastavni plan i program za osnovnu školu, (2006). Zagreb: Ministarstvo znanosti, obrazovanja i športa.

Pace, A. (2012). Musica e formazione primaria, Padova: Ed.Libreriauniversitaria.it.

Porobić, S.; Hrvanović M. (2009). Uloga nastavnika muzičke i likovne kulture u unapređivanju moralnih osobina učenika osnovne škole,U: Kadum,V. (ur.), Monografija Međunarodnog znanstvenog skupa, Pula: Sveučilište Jurja Dobrile u Puli, str. 499-512

Radičević, B.; Šulentić Begić J. (2010). Pjevanje u prvim razredima osnovne škole, Život i škola, br. 24 (2/2010), god. 56. str. 243-252.

Radole, G., (1976). Cenni critici di bibliografia del canto popolare e istriano. Canto popolare ed elaborazione artistica nella musica corale. U: Atti del VII Convegno europeo sul canto corale, Gorizia, str. 79-82.

Rojko, P. (2002). Je li moguć sustavan glazbeni odgoj u ranom djetinjstvu, Tonovi. Časopis glazbenih i plesnih pedagoga, br.40, HDGPP, Zagreb, str.74-79.

Rojko, P. (2009). Obrazovanje učitelja glazbe u svjetlu današnjih i budućih promjena u glazbenom obrazovanju, U: Vidulin-Orbanić., S. (ur.), Zbornik radova Prvog međunarodnog simpozija glazbenih pedagoga, Sveučilište Jurja Dobrile u Puli, Pula, str. 25-36.

Rojko, P. (2016). Prijedlog Nacionalnog kurikuluma glazbenoga predmeta Glazbena kultura i Glazbena umjetnost, veljača2016.,Tonovi. Časopis glazbenih i plesnih pedagoga, br.67, HDGPP, Zagreb, str. 55-99.

Sam Palmić, R. (2013). Tragom zavičajnih napjeva u osnovnoškolskom glazbenom kurikulu do interkulturalnosti, Školski vjesnik 62, str. 559-572.

Starec, R. (1985). Pive, simbolo e fiavole: tre strumenti musicali del folklore istriano. U: Atti e memorie della Società istriana di archeologia e storia patria, n. 33, 1985, str. 169-215

Starec, R. (1986). La musica popolare istro-veneta nel contesto etnomusicale nord-adriatico. U: Atti del Convegno "La cultura istro-veneta come identità e veicolo di comunicazione negli scambi culturali dell'Alto Adriatico (23 marzo 1985)", Circolo Istria, Quaderno III, str. 42-51. 
Svalina, V.; Škojo T. (2009). Nacionalni kurikulum i glazbeno obrazovanje budućih učitelja, U: VidulinOrbanić, S. (ur.), Zbornik radova sa Prvog međunarodnog simpozija glazbenih pedagoga Glazbena pedagogija u svijetlu sadašnjih i budućih promjena, Sveučilište Jurja Dobrile, Pula, str. 115132.

Šulentić Begić, J. (2009). Hrvatski nacionalni obrazovni standard i permanentno obrazovanje učitelja glazbe, U: Vidulin-Orbanić., S. (ur.), Zbornik radova Prvog međunarodnog simpozija glazbenih pedagoga, Sveučilište Jurja Dobrile u Puli, Pula, str. 133-151.

Šulentić Begić, J. (2010). Pjevanje kao izabrana aktivnost otvorenog modela nastave glazbe, U: Vrandečić, T., Didović, A. (ur.), Monografija umjetničko-znanstvenih skupova 2007.-2009. Glas i glazbeni instrument u odgoj i obrazovanju, Učiteljski fakultet Sveučilišta u Zagrebu, Europski centar za napredna i sustavna istraživanja, str. 60-67.

Šulentić Begić, J.; Bubalo, J. (2014). Glazbene sposobnosti učenika mlađe školske dobi, TonoviČasopis glazbenih i plesnih pedagoga, br.64. HDGPP, Zagreb, str. 66-78

Veljović, M. (2005). Istarski tonski niz: od napjeva do atonalitetne strukture, U: Zbornik radova IV. Međunarodnog simpozija „Muzika u društvu“, Sarajevo: Muzikološko društvo FBiH, Muzička Akademija u Sarajevu.

Vidulin-Orbanić S. (2010). Glazbeno obrazovanje u Istri danas: pedagoške implikacije, U: Gortan Carlin, I., P., (ur.), Zbornik radova sa 6. međunarodnog muzikološkog skupa „Iz istarske glazbene riznice“, Ruralna i urbana glazba istarskog poluotoka, Novigrad: Katedra Čakavskog sabora, str.143-158.

Vidulin-Orbanić, S.; Pejić-Papak, P. (2009). HNOS i suvremena škola: Reakcija ili interakcija, U: Kadum, V. (ur.) Monografija s Međunarodnog znanstvenog skupa, Sveučilište Jurja Dobrile, Pula, str.15-32.

\section{Traditional Music of Istria in Teaching Music Culture in the Lower Classes of Elementary School}

Abstract: Traditional music is integrated into the life of every human community and it reflects the way of thinking and lifestyle of people who have created it, preserved it and passed it on to younger generations. In addition to being an expression of creativity and desire for fun, traditional music is part of the customs and rituals related to the daily life and important events in the life of every individual. In the past, traditional music was passed down for generations by word of mouth. Nowadays, the progress of technology and means of communication has changed the way of oral traditions and primary schools have the task to preserve cultural heritage sites and transmit them to the younger generations. According to the primary school curriculum in the Republic of Croatia (2006), the teacher is free to choose the traditional motifs and melodies, as well as other traditional contents, which may be included in their implementing curriculum. This paper presents the data concerning the realization of such contents. A survey, based on the representation of traditional music in lower primary school classes in the subject Music Culture, was conducted in southern Istria to check the teachers' attitudes in the matter. The research has pointed out the differences in the implementation of traditional contents caused primarily by the teachers' personal standpoints. In preserving the musical heritage, the contemporary organized educational system has an invaluable role. Using regular and extracurricular activities, and the correlation with other curriculum areas, teachers can, using traditional music complement the student's knowledge and contribute to the development of their skills.

Keywords: traditional music of Istria, curriculum, Music Culture, Music Culture teachers 


\section{Traditionsmusik Istriens im Musikunterricht in der Primarstufe}

Zusammenfassung: Die Traditionsmusik ist ins Leben jeder Menschengemeinschaft eingewebt und in ihr spiegeln sich die Denkweise und der Lebensstil der Menschen, die diese Musik schufen, sie bewahrten und von Generation zu Generation weitergaben. Traditionsmusik ist Ausdruck von Kreativität und Wunsch zu unterhalten, aber auch Bestandteil von Bräuchen und Ritualen, die im alltäglichen Leben und in wichtigen Ereignissen jeder einzelnen Person eine Rolle spielen. Einst wurde die Traditionsmusik ausschließlich mündlich überliefert. Dank dem technischen Fortschritt, den Kommunikationsmitteln und der VervolIkommnung der Unterrichtsmethoden wird dies zunehmend Aufgabe der Schule. Laut Curriculum für die Grundschule, das in der Republik Kroatien seit 2006 in Kraft ist, haben Musiklehrer die Freiheit traditionelle Motive, Gesang und andere traditionelle Inhalte zu wählen und in ihr Unterrichtsprogramm einzubauen. In dieser Arbeit werden die Angaben über die Realisierung dieser Inhalte angezeigt. In der empirischen Untersuchung mittels Fragebogen wurden die Haltungen von Primarstufenlehrern Südistriens zu der Präsenz von Traditionsmusik im Musikunterricht abgefragt. Die Forschungsergebnisse weisen auf Unterschiede in der Realisierung der traditionellen Inhalte hin, die in erster Linie durch persönliche Haltungen der einzelnen Lehrer bzw. Musiklehrer bedingt sind. Das zeitgenössische organisierte Erziehungs- und Bildungssystem spielt bei der Bewahrung des Musikerbes eine erhebliche Rolle. Im regulären Unterricht, im AG Angebot, sowie durch fachübergreifende Verknüpfung mit anderen Bereichen können Lehrer mithilfe der Traditionsmusik die Bandbreite der Erkenntnisse erweitern und zur Förderung der Kenntnisse und Fertigkeiten beitragen.

Schlüsselwörter: Traditionsmusik Istriens, Curriculum, Musikunterricht, Musiklehrer 